\title{
INITIAL INVESTIGATIONS OF COIL HEAT EXCHANGER UTILIZING WASTE HEAT FROM AIR CONDITIONING SYSTEM
}

\begin{abstract}
In this paper the selected results of testing of tube coil heat exchanger have been presented. The investigated heat exchanger is designed to preheating domestic warm water with the use of waste heat from air conditioning system. The tested device consists of finned tube coil heat exchanger immersed in the thermal storage tank. The tank is equipped with three heating coils and the cylindrical-shaped temperature stratification system. Two coils use water as a heating medium. The third, double-wall heat exchanger coil is filled with the refrigerant from the air conditioning system. The industrial stand enables the experimental investigations of thermal and flow characteristics of the exchanger. In the paper the authors present the technological scheme of the test stand, specification of components of the stand, research possibilities and the exemplary results of characteristic temperature and pressure measurements.
\end{abstract}

Keywords: tube coil heat exchanger, thermal-flow characteristics, temperature stratification

\section{Introduction}

Coil heat exchangers have wide application in several fields of engineering. They are used in refrigerators, chemical reactors, steam generators, domestic hot water systems. In general they can be used as coolers, heaters, condensers or evaporators. Coiled tube heat exchangers offer some unique advantages: heat transfer between more than two streams, a large number of heat transfer unit and high operating pressure. Helical coils are used for various processes since they can accommodate a large heat transfer area in compact space, with high heat transfer coefficients. Coil heat exchangers were the subject of many investigations. Papers [1-6] are the examples of works on exchangers considered.

The present paper deals with the special type of coil heat exchanger. An important feature of the exchanger is waste heat recovery. The exchanger con-

${ }^{1}$ Autor do korespondencji/corresponding author: Joanna Wilk, Politechnika Rzeszowska, 35-959 Rzeszów, al. Powstańców Warszawy 12, tel.: (17) 8651288, e-mail: joanwilk@prz.edu.pl

2 Robert Smusz, Politechnika Rzeszowska, e-mail: robsmusz@prz.edu.pl 
sists of three finned coils immersed in the tank. Two coils are standard designed to warm the hot domestic water in the storage tank with the use of the water as a heating medium. The third coil is filled with the refrigerant which transfers the waste heat from the air conditioning system. The special buffer layer filled with the nanofluid is mounted in the coil to prevent possible refrigerant leakage. $\mathrm{Cu} /$ water nanofluid is used to reduce a thermal resistance of the buffer layer. Thermal tank is equipped with a temperature stratification device. It is designed for improving of heated water stratification level. Presented in this paper the industrial stand enables experimental investigations of the proposed coiled tube heat exchanger. The main aim of the investigations was to determine the influence of the application of the special device on the stratification of water temperature in the storage tank of the exchanger. The second goal was to obtain the thermal efficiency of the heat recovery system.

\section{Test stand for investigations of coil heat exchanger}

The presented test stand is equipped with measuring system for obtaining thermal and flow characteristics of the exchanger. It is based on the measure of: temperature, pressure, flow rate and heat loss with the use of special apparatus. The applied data recording system allows to collect and store measuring data. The technological scheme of the experimental stand is shown in figure 1. In turn figure 2 presents the general view of test section including the storage tank with applied sensors, supply pipes of heat exchanger and computer system for measuring control and data acquisition. The main elements of the experimental stand are: the storage tank, upper and lower water coils, the coil with refrigerant, the additional buffer tank and the thermostat. Two water coils are supplied with heating water with the use of the pump with a manifold. To ensure stabilization of the heating water temperature the additional buffer tank was applied. The third coil that uses waste heat is connected with the air conditioning system. Regulation of the flow rate of the working media is carried out with flow control valves. The measuring equipment located on the test stand enables measurements of the following parameters characterizing the operation of the considered heat exchanger:

- supply and return temperatures of working medium in each coil,

- inlet and exit pressure of working medium if each coil,

- volumetric flow rate in water coils,

- temperature of the outer surface of the tank,

- ambient temperature,

- heat loss from the outer surface of the storage tank.

To determine the thermal power and pressure drop in coils the following sensors are used:

- six resistive temperature sensors AP-TOP-VFGPt100 (Kompart Pomiar), 
- six piezo pressure transducers A-10 (WIKA) of measurement range $0 \div 6$ bar mounted on water coils,

- two piezo pressure transducers A-10 (WIKA) of measurement range $0 \div 40$ bar mounted on the coil of heat recovery,

- two turbine flow meters TM44 (Tecfluid).

1 - Regulator

2 - Additional buffer tank

3 - Storage tank of domestic hot water

4 - Upper water coil

5 - Lower water coil

6 - The coil of heat recovery

7 - Pump

8 - Strainer filter

9 - Check valve

10 - Shut-off valve

11 - Analog manometer

12 - Analog thermometer

13 - Manifolds

14 - Flow control valve

15 - Turbine flow meter

16 - Temperature sensor

17 - Pressure transducer

18 - Vent valve

19 - Expansion vessel

20 - Backflow preventer

21 - Safety valve

Fig. 1. Technological scheme of the experimental stand for the test of tube coil heat exchanger using waste heat from air conditioning system

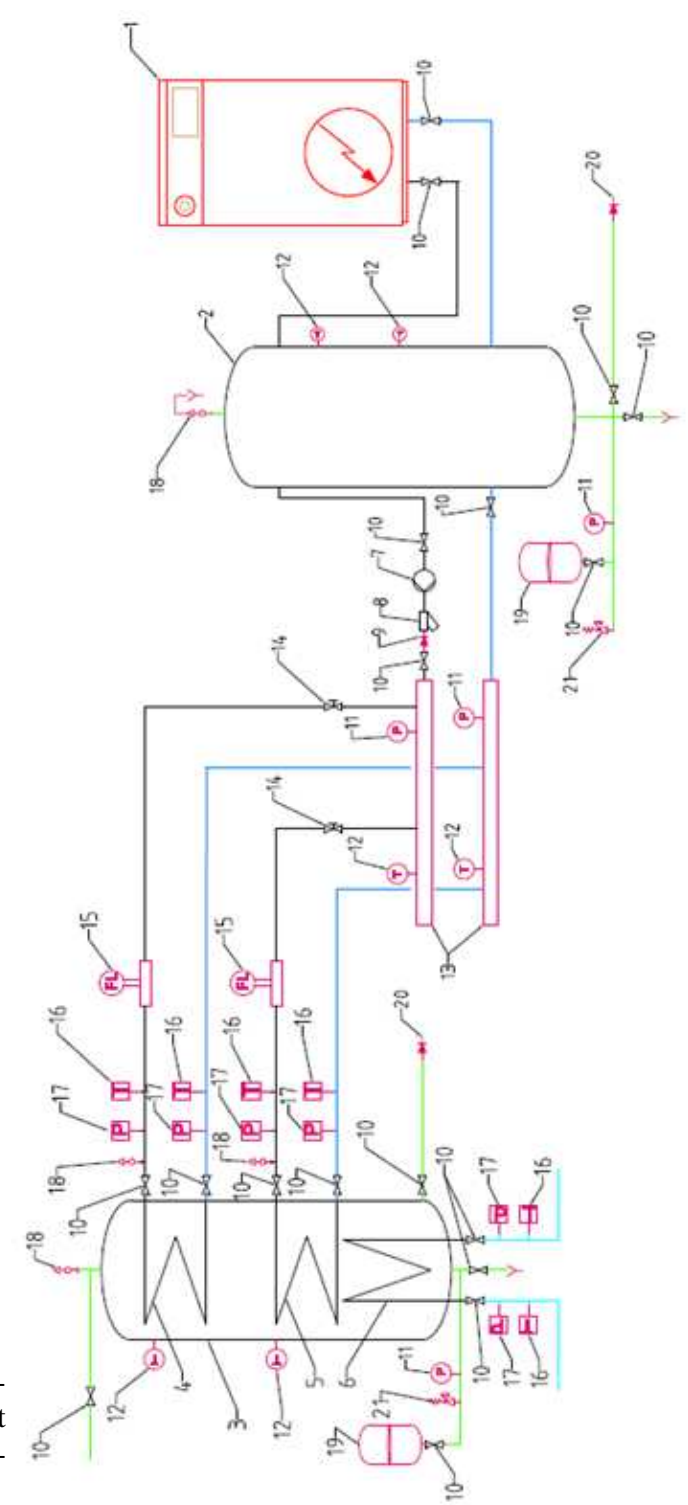



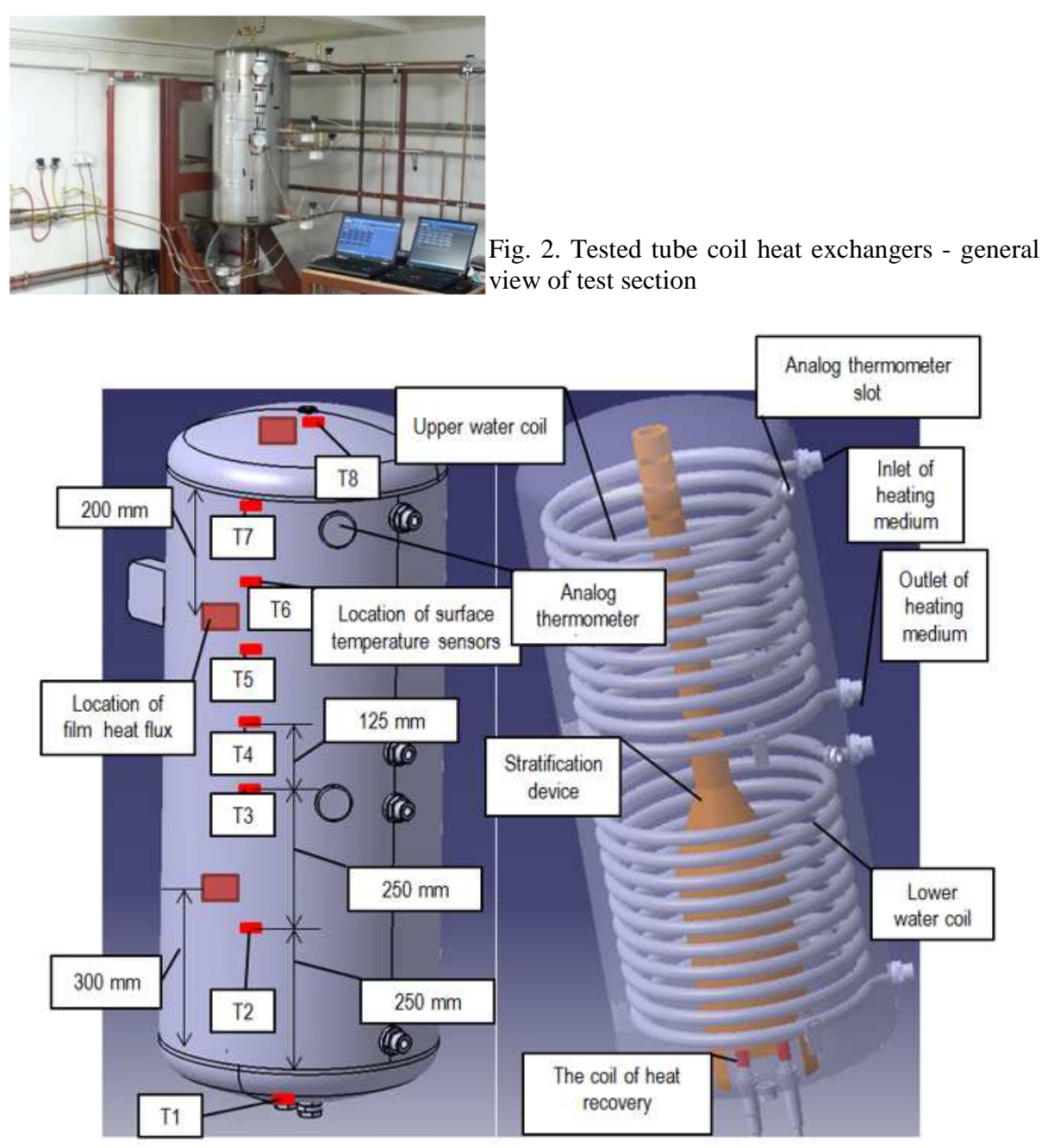

Fig. 3. Location of measuring sensors on the surface of the storage tank and the visualization of coil heat exchanger system with the stratification device

The eight resistive temperature sensors M-FK 1020 (Heraeus Sensor-Nite $\mathrm{GmbH}$ ) are mounted on the surface of the tank to measure the stratification of domestic hot water temperature in the storage tank. To determine heat loss from the tank three film heat flux sensors HFS-3 (OMEGA) are used. Two sensors have a sensitivity of $1.9 \mu \mathrm{V} / \mathrm{W} / \mathrm{m}^{2}$, one sensor has a sensitivity of 22.3 $\mu \mathrm{V} / \mathrm{W} / \mathrm{m}^{2}$. Additionally, one resistive temperature sensor TP-992Pt1000 (CZAKI Termoprodukt) is used to measure the ambient temperature.

The power supply of temperature and pressure sensors is realized by twochannel power adapters Aplisens Zl-25-01. Data logging is carried out with the recorder GL820 and GL220 (DATAQ ${ }^{\circledR}$ ). Sequence of measurements is con- 
trolled by the software DATAQ®. The location of heat flux and temperature sensors on the surface of the tank is presented in figure 3. Temperature sensors $\mathrm{T} 1$ and $\mathrm{T} 8$ are placed at the bottom and the top of the tank, respectively. They measure the temperature at the highest and lowest point of the storage tank. A total of 26 parameters is measured and recorded with the use of data acquisition system.

\section{Results of measurements}

Basic measurements of the considered tube coil heat exchanger were performed during thermal supplying of the storage tank with the use of the coil filled with the refrigerant which transferred the waste heat from the air conditioning system. Changes in time of supply and return temperatures of the refrigerant being working medium are presented in figure 4 . Figure 5 shows changes of the pressure at the inlet and outlet of the coil of heat recovery.

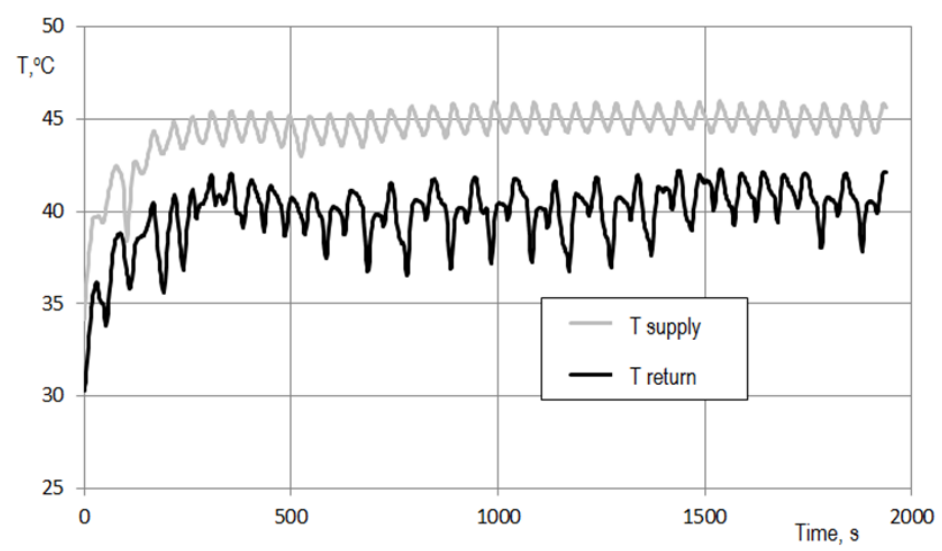

Fig. 4. Supply and return temperature of the refrigerant - R407C - the working medium from air conditioning system

The mean supply temperature of working medium during the process of the heating of water in storage tank with the use of the coil of heat recovery was equal to $44.74^{\circ} \mathrm{C}$. The return temperature was respectively $40.2^{\circ} \mathrm{C}$. The mean value of supply pressure was $1601.6 \mathrm{kPa}$ and of return pressure was $1594.6 \mathrm{kPa}$. The pressure drop of the refrigerant during the flow through the coil heat exchanger was equal to $7 \mathrm{kPa}$. Exemplary results of measurements of water in the storage tank are presented in figure 6 . Temperature changes during the heating process measured with sensors T1, T8 located at the bottom and the top of the tank are shown. Additionally, the temperature from sensor T2 (according to Figure 3 ) is presented. The point T2 is located at a height relative to the bottom 
of the tank equal to 0.27. The example in Figure 6 refers to water heating process with the use of the coil exchanger of heat recovery system.

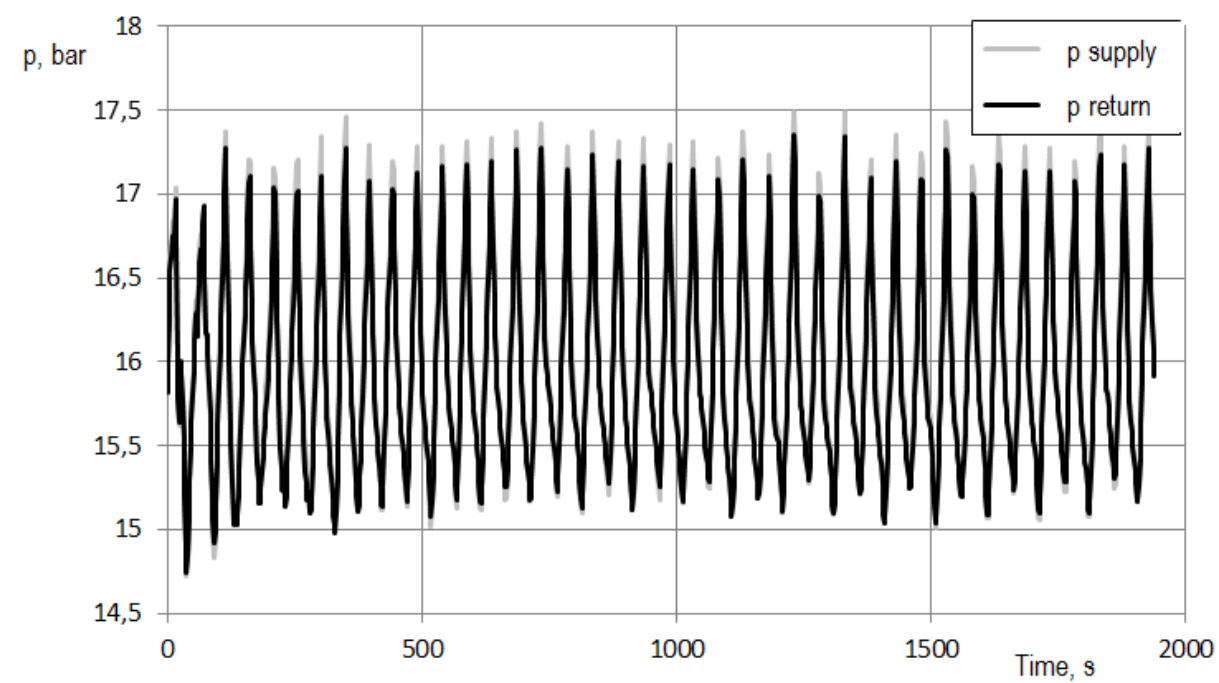

Fig. 5. Supply and return pressure of the refrigerant

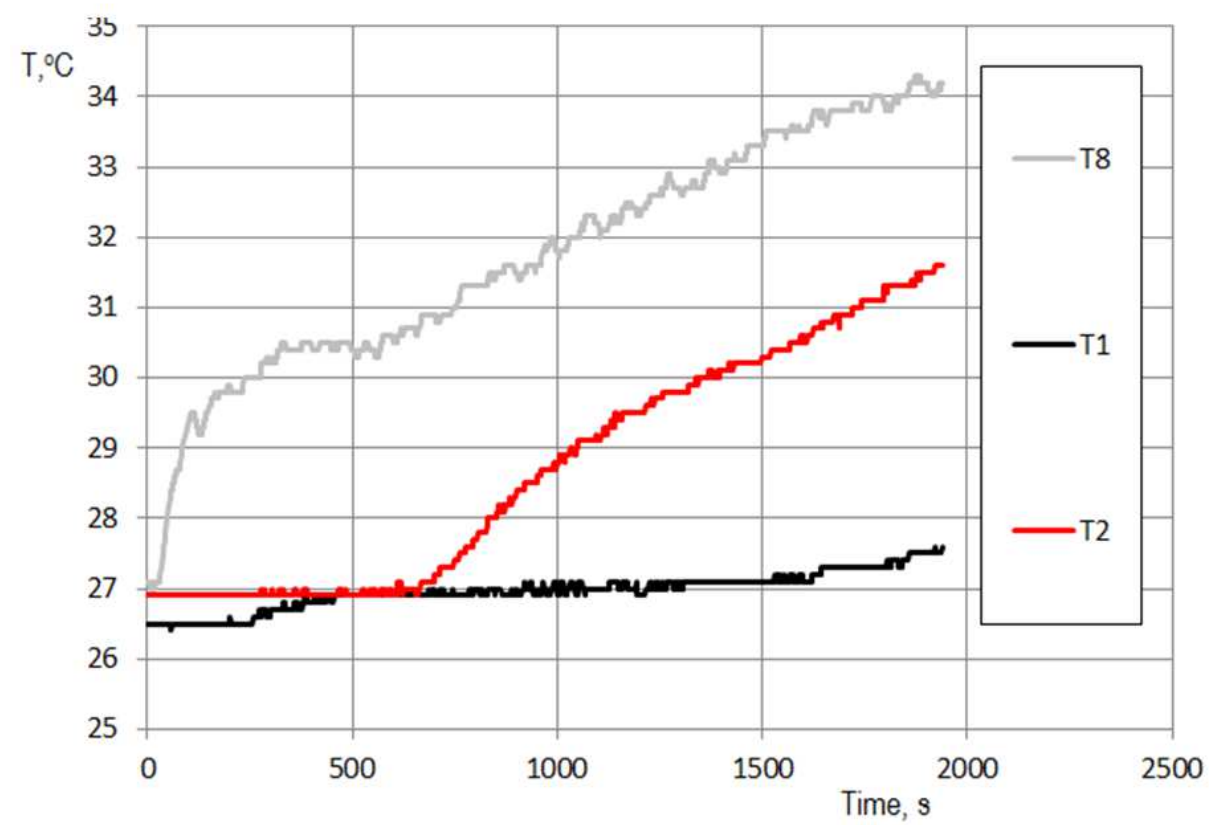

Fig. 6. Temperature of heated water in the storage tank in a function of heating time 


\section{Conclusions}

The presented test stand has been built to research the tube coil heat exchanger designed to warm domestic hot water with the use of waste heat from air conditioning system. The test stand enables the experimental investigations of thermal and flow characteristics of the exchanger. On the basis of some selected results of the investigation the following conclusions on the operation of the exchanger can be formulated:

1) Supply and return temperature of working medium is stabilized after about 250 seconds' thermal start-up. It is the result of thermal inertia of the installation and the temperature sensors.

2) The observed oscillations of temperature and pressure of working medium are the effect of cyclic operation of the compressor unit of the air conditioning system.

3) The applied refrigerant $\mathrm{R} 407 \mathrm{C}$ is a superheated vapor at the inlet of the coil. Saturation temperature of $\mathrm{R} 407 \mathrm{C}$ is $36.4^{\circ} \mathrm{C}$, at return pressure 15.946 bar. Thus, at the exit of the coil the refrigerant is a saturated liquid-vapor mixture. The partial condensation of the refrigerant is the result of a relatively high water temperature in the storage tank.

4) The relatively fast water heating process is observed. This is represented by changes of temperature $\mathrm{T} 2$ and $\mathrm{T} 8$ as shown in figure 6 . Hot water is transported to the upper zone of the storage tank by a system of temperature stratification.

5) In the bottom zone of the tank the increase in water temperature is low. Thus, the difference between refrigerant temperature and the temperature of water in the tank does not decrease and the operation of heat recovery system is improved.

\section{References}

[1] Genić S.B., Jaćimović B.M., Jarić M.S., Budimir N. J., Dobrnjac M. M.: Research on the shell-side thermal performances of heat exchangers with helical tube coils, Int. J. Heat Mass Transfer, 55 (2012 4295-4300.

[2] Logie W.: Immersed Coil Heat Exchangers, Solartechnik Prüfung Forschung, 22 (2007) 1-11.

[3] Prabhanjan D.G., Raghavan G.S. V., Rennie T.J.: Comparison of heat transfer rates between a straight tube heat exchanger and a helically coiled heat exchanger, Int. Comm. Heat Mass Transfer, 29 (2002) 185-191.

[4] Smusz R., Wilk J.: Coil heat exchanger with the nanofluid filled buffer layer, Appl. Mech. Materials, 831 (2016) 223-231.

[5] Smusz R, Wilk J.: Modeling of heat transfer processes in filled with nanofluid the buffer layer of coil heat exchanger, J. Power Technologies, 20 (2016) in the process of publishing. 
[6] Zachár A.: Analysis of coiled-tube heat exchangers to improve heat transfer rate with spirally corrugated wall, Int. J. Heat Mass Transfer, 53 (2010) 3928-3939.

\section{BADANIA WSTĘPNE WĘŻOWNICOWEGO WYMIENNIKA CIEPŁA WYKORZYSTUJĄCEGO CIEPLO ODPADOWE Z SYSTEMU KLIMATYZACJI}

\section{Streszczenie}

W pracy przedstawiono wybrane wyniki badań wężownicowego wymiennika ciepła. Testowane urządzenie jest przeznaczone do podgrzania ciepłej wody użytkowej przy użyciu ciepła odpadowego pochodzącego z systemu klimatyzacji. Badane urządzenie stanowi wymiennik ciepła złożony $\mathrm{z}$ użebrowanych wężownic zanurzonych $\mathrm{w}$ zbiorniku termicznym. Zbiornik jest wyposażony w trzy wężownice grzejne oraz cylindryczny układ stratyfikacji temperatury. Czynnikiem roboczym w dwóch wężownicach jest woda. Trzeci dwuścienny wężownicowy wymiennik ciepła jest zasilany czynnikiem chłodniczym z układu klimatyzacji. Stanowisko przemysłowe umożliwia przeprowadzenie badań eksperymentalnych charakterystyk cieplno-przepływowych wymiennika. $\mathrm{W}$ pracy autorzy przedstawili schemat technologiczny stanowiska badawczego wraz z wykazem i charakterystyką jego poszczególnych elementów. Podano również możliwości badawcze oraz przytoczono przykładowe wyniki pomiarów temperatur i ciśnień charakterystycznych.

Słowa kluczowe: wężownicowy wymiennik ciepła, charakterystyki cieplno-przepływowe, stratyfikacja temperatury

DOI: $10.7862 / \mathrm{rm} .2017 .11$

Otrzymano/received: 12.09 .2016

Zaakceptowano/accepted: 24.11.2016 